\title{
記憶シナプスの可塑性とインパルス頻度 ATP，アデノシンの役割
}

\section{東京都神経科学絵合研究所 黒 田 洋一郎}

\begin{abstract}
Synaptic connections in the brain are functionally and morphologically changed depending on environmental stimuli. A "tracing circuit" model is proposed that a "tracing circuit" of neurons corresponding to human descriptive memory is established by synaptic competition and kept by the following sprouting and increase of the number of synapses in the circuit. The physiological roles of adenosine derivatives are considered to be agonists of two mechanisms of synaptic competition : lateral inhibition and central facilitation. Released ATP can facilitate novel synapse formation through ecto-protein kinase. A new hypothesis is proposed that the occurance of long-term potentiation (LTP) or of long-term depression (LTD) depends on the frequency of conditional stimulation and can be induced by different presynaptic adenosine receptors.
\end{abstract}

human memory/impulse frequency/Adenosine/ATP/Long-term potentiation(LTP)

Long-term depression(LTD)/synapse formation/ecto-protein kinase

\section{1.はじめに}

脳の機能の発達は, ニューロン間に適切なシナブス 結合が形成されることによる。この結合は基本的には 遺伝情報により決定され，行動のもととなっている. しかしこの結合は環境からの影響（外界からの刺激） で後天的に変化しうる.シナプスの環境要因に対する 機能的・形態的な変化は可塑性と呼ばれ，これが学習 と記憶のメカニズムの根底にあると古くから考えられ ている.

多くの場合, シナプス結合の長期にわたる変化が生 後の外的刺激によって起こる時期は，発達段階での一 定の感受性期に限られている。例えば, アヒルの刷り 込み現象は餒化直後に限られ”，ネコ視覚系の臨界期 は生後 4 ヶ月頃迄である”.

しかしながら一方では，成熟過程における学習と記 憶, 即ち成熟脳におけるダイナミックなシナプス結合 の変化を支持する知見も集積されつつある.

ここでは，ヒト脳の持つ言語・思考機能のもととな

Roles of ATP and adenosine derivatives for frequency-dependent changes of synaptic connections, long-term potentiation (LTP) and long-term depression (LTD).

Yoichiro KURODA

Department of Neurochemistry, Tokyo Metropolitan Institute for Neurosciences.
る陳述的記憶の分子メカニズムを探る試みとして， “トレーシング回路”と呼ばれる、ニューロン回路網 が, ヒトの陳述的記憶の実体であり，成熟後もシナプ ス結合の可塑性が継続されている大脳皮質連合野にお いて機能しているというモデルを述べる.

まず記憶ニューロン回路中のシナプス（記憶シナプ ス）の伝達効率を変化させる分子機構における, tracingで生じるインパルス頻度の重要性についてふれる. 高頻度刺激後に起こる長期増強（LTP）と長期抑圧 （LTD）は少なくとも海馬などでは刺激の頻度に依存 して同じシナブスでも起こり得る.この単一シナプス の伝達効率の長期変化について, affinity の異なる 2 種類のアデノシン受容体の関与があるのではないかと いう新しい仮説を提唱する.

また使用頻度の高いシナプスが活動依存的に，より 使用頻度の低いシナプスを除去するという「シナプス 競合」も“トレーシング回路説”の骨子となる細胞レ ベルのメカニズムである.このシナプス競合において も ATP及びアデノシン関連物質が側抑制 lateral inhibition 及び中心促通 central facilitation に関与してい ること，また ATP が細胞外に活性中心を持つ ectoープ ロテインキナーゼを介してシナプス形成を促進してい る可能性についても言及する. 


\section{2、ヒト脳における記憶の}

“トレーシング回路”モデル

\section{ヒトの陳述的記憶の特徵}

ヒトの持つ学習・記憶能力は他の生物に比べて最も 進化しており, 次のような特徵を持つ.

1) 著しく大きな記憶容量をもち，一般にその内容は 遭伝的な規制を受けていない。いわゆる Random Acceses Memory(RAM)をもつ.

2) たった一回の経験でも記憶することが可能で，繰 り返しによる学習（リハーサル学習）を必ずしも 必要としない。

3 ）記憶されたもののなかには非常に長期に（中には ヒトの一生に渡って）保持されるものがある。

\section{陳述的記憶と大脳皮質連合野}

記憶のもととなる感営情報は脳内で処理・統合され 基本的にはインパルスの頻度に变換されて, 最終的に は大脳皮質連合野に入っていく。ヒト脳の大きな特徴 としてこの大脳皮質連合野が，また機能がよくわかっ ていないにも関わらず，非常に発達していることが挙 げられる. 大脳皮質のニューロンは 6 層に区分される 層構造を成しており，また平面的にはカラム構造とい われるニューロン群のモヂュール構造がある．それぞ れのニューロンはその細胞体抢よび樹状突起.上に数百 から数万といわれるシナプス結合を持ち他のニューロ ンと複雑につながっている．このような遺伝的には機 能がはっきり決まっていないらしい，ほとんどランダ ムといえるようなニューロン間の配線, すなわちて長 度の高いシナプス結合がヒトの膨大な記憶容量を支え ている.

このハードウェアをどのように使って記憶を初めと する種々の高次機能が実現されているかは未だよくわ かっていない. しかし今，それぞれの感覚情報をはこ ぷインパルス群がニューロンを伝わりながら作り上げ る空間的・時間的な 4 次元のニューロン回路網がその 高次機能の実体であることは確かであろう。

“トレーシング回路”仮説

Hebb が1949年に提唱した可塑性シナプスによる ニューロン閉回路説，いわゆる反響回路説を発展さ せた“トレーシング回路”モデル（図 1，2）にによれ ば，記憶過程は以下のように理解される。感覚器官 からのインパルス頻度としての電気信号は, まず一連 の脳内神経細胞群に伝わる，その結果できたニューロ ン回路のうち一部は閉回路を形成し，インパルス群が 閉回路及びそれにつながるニューロン回路を循環・伝

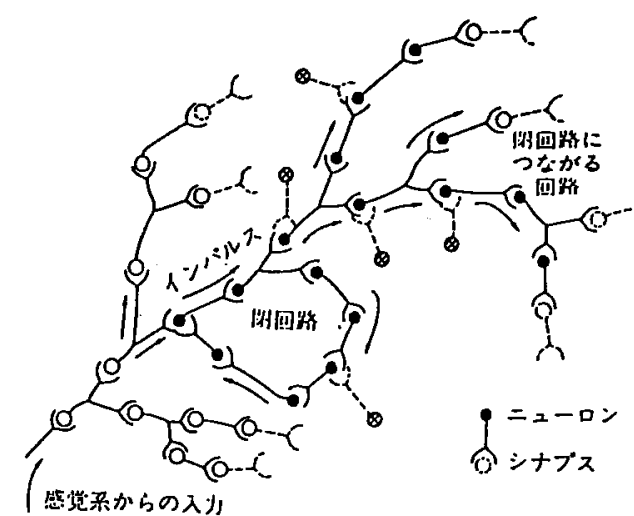

図1，ヒトの長期記憶の“トレーシング回路”モデル (文献 4 を改変)

感覚器からの入力は脳に到達し，閉回路とそれ につながる回路を伝わる（図中では複雑な 4 次元 構造は単純化し，マイクロサーキットは省いた). インパルスが回路中を繰り返し伝わるとき，頻発 刺激後増强(PTP)により回路中のすべてのシナプ スが機能的に促通しているこの“トレーシング 回路”のパターンの活動は記述性短期記憶に相当 する．回路外を起始とする軸索のシナプスの選択 的除去の結果, シナブス結合が增加し，回路内の シナプス伝達奻率が機能的に増強され，回路が形 態的に残されると，その同じ回路のパターンは長 期記憶されたことになる．異なる時間経緯のシナ プス変化は、入力が回路を伝わる間高頻度促通が すべてのシナプスを刺激することにより引き起こ される，生化学的カスケードの結果である。 “トレーシング回路”中のニューロン，○“ト レーシング回路”につながるニューロン，囚競合 により選択的に消去された回路外ニューロン（図 2 参照). もし閉回路内に入力があると同じ回路 がトレースされ，同じような電気活動が発現する のであろう。これが記憶の想起にあたる。

播する.その時間内だけは一つ一つの記憶に対応する ニューロン回路が電気活動の継続として保たれる.こ れが数秒程度保持される短期記憶を説明するメカニズ ムとなる，その保持時間は抑制入力が電気活動を減哀 させる程度によって決定される，更にこのような二 エーロン回路は回路中のシナブスの可塑性によって長 期的に保たれ得る。これが長期記憶である、シナプス で異なった時間経過を持つ，いくつかの物質変化が起 きこれれよって記憶回路内のシナプス結合が潜在的 に保たれ，記憶は保持される. その後新しいインパル スがこの記憶回路に入ればそのニューロン回路のパ ターンは再現され記憶がよみがえる，すなわち想起さ れるわけである.“トレーシング回路”モデルによれ ばヒトが一度しか起こらない経験を記憶できる事も良 く説明できる．たった一回の刺激でも“トレーシング 

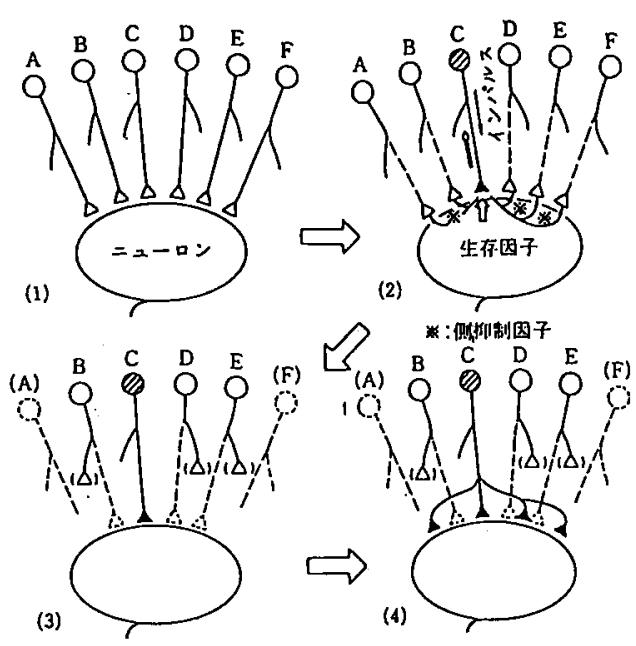

図 2. 使われないシナプスの選択的除去と神释釉末上の 発芽による支配的入力の安定化（文献 4)

(1) シナブスの過剩な結合：発達後, 多くの ニューロンは脳内の他の多くのニューロンに投射 する.ある程度の特異性と減少は遺伝的に決定さ れている. (2) 側抑制：たとえば, “トレーシン

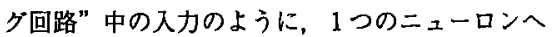

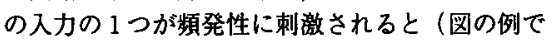
はCニューロンからの入力), シナプス活動を抑 制する物質が放出される(詳しくは本文参照). ATP とアデノシン関連物質はこのような側抑制 物質の 1 つである. (3) 生存因子のとり込みと神 释死：一方, 活動依存的に生存因子のとり込みが 神経終末で起こる.したがって，㧕制された， 女 しくは使われないシナプスは生存因子をとり这め なくなる. 生存因子をとり込めなくなったニュー ロンは死んでなくなる（図の例では A と F二ュ 一ロン). (4) 使用頻度の高い入力からの発芽と 新しいシナブス形成：使用頻度の高い入力の神释 終末より発芽し，投射するニューロン上の空いた 表面に新しいシナプスを形成する．シナプス数の

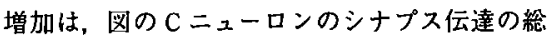
効率を上昇させ, 長期間形態を維持するのにも役 立つ.

回路”内をインパルスが絽り返しトレースし, 脳内の 記憶シナブスにおいてリハーサルが行われるからであ る.

ヒトの記憶に本当に閉回路が関与しているのか, 閉 回路はどこにあるのかという疑問にたいしては，いま のところ実験的な証明が技術的に困難である.しかし， 両側の海馬を失った記憶障害患者 H. M. の例)などを 考え合わせると，陳述的記憶において海馬領域が二ュ 一ロンの閉回路結合を形成し，連合野に形成される記 憶回路にインパルスを絽り返し送り込む役割を果たし ていると考えることもできる.
“トレーシング回路”とシナプス可塑性

学習と記憶はシナプス結合の機能的, 形態的変化に より起こるという考えは古くからあっだ．そのシナ プスの可塑性には大きく分けて既成のシナプスの伝達 効率の変化と，新しいシナブス形成などによるシナプ ス結合の変化がある. 前者は電気生理学的に観察しゃ すくこれまでよく研究されてきた．しかも高頻度刺激 後増強 $(\mathrm{PTP})^{7)}$ や海馬などでみられる長期増强(LTP $)^{8)}$ のように，変化が高頻度刺敨によってひきおこされる 場合がほとんどであることは興味深い.なぜなら“ト レーシング回路”モデルによれば記憶回路内のシナフ スのみにインパルス群が高頻度で通過するはずだから である.

しかしながら各種の機能を持つ生体分子の代謝回転 による半減期が最大でも 4 週間程度であるらしい事を 考えに入れると, 単一シナブスでのシナプス伝達の効 率変化によって年単位以上持続するヒトの長期記憶を 説明できるとは考えにくい. “トレーシング回路”モ デルによれば回路中の未熟なシナプス結合は選択的除 去とシナプス発芽により堌強される（図 2 ）ので, 構 成蛋白質の代謝回転の問題は生じない.

\section{3．刺激頻度に依存したシナプス伝達効率の 可塑性, LTP と LTD.}

まず記憶シナプスにおける短期から長期への橋渡し となる単一シナプスでの伝達効率の可塑性, 長期增強 $(\mathrm{LTP})^{81}$ や長期抑圧 (LTD) に法

LTP はいわゆる記憶のモデル現象として盛んに研 究されており，最近では大脳皮質など海馬以外のシナ プスでも起こることが知られている，また，小脳で観 察されたLTDは，驚くべきことに海馬でも LTP と同 時に異なった部位のシナプスでみられることが判明し $た^{10)}$.おそらく実際には同じ海馬シナプスでLTPと LTDが起こりうる．それならばLTPとLTDをわけ るものは何であろうか. 現在までの知識に基づけば, インパルス頻度"1”（およびそれにほぼ比例して神経終 末などから放出されシナプス間隙で増加する“インパ ルス頻度メッセンジャー物質” の局所濃度) が LTP と LTD の発生を決めている要素の一つではないかと 考えられる．抢そらく，海馬では比較的低頻度の刺激 が LTDを起こし，ある一定以上の高頻度の刺激が LTPを起こす可能性が高い（図 4 ）．LTPは記憶のモ デルとされているが，ヒト海馬は長期記憶の眝蔵庫で はないので, 必ずメモリーは消去されなければならな い. 海馬 CAl 領域では数 $\mathrm{Hz}$ 位の低頻度刺激で LTP 
か解除できるのは，LTD 様の現象が LTPを打ち消す のであろう。“インパルス頻度（記憶）メッセンジャ 一物質”としてはグルタミン酸やATP とその分解産 物であるアデノシンが有力候補で, 細胞内 $\mathrm{Ca}^{2+}$ など 二次メッセンジャー物質や機能たんぱく質のリン酸化 と，複雑な分子カスケードを構成しており，6章でく わしく述べる.

\section{4. 発達脳, 成熟脳における}

\section{シナプス結合の可塑性}

発達脳でシナブスを作れなかったニューロンが生存 因子を受け取る事ができずに選択的に死ぬ事 ${ }^{(2) .131}$ や使 用されない過剩なシナプスがシナプス競合 などによ り除去される事が知られている. シナプス競合は異な る入力間で活動性の不均衡が存在し, シナプス活動性 に依存してシナプス間隙に放出される “側抑制因子” と前述の生存因子を考慮すると説明できる事がかかっ て来た（図 2 ).

成熟脳におけるシナプス結合の変化は実験的証明が より困難なためこれまであまり研究されず，ヒトを初 め哺乳動物の脳では発生・発達の一定の時期迄にシナ
プス形成は全て終わってしまい，成熟脳では障害をう けないかぎり新しいシナブスは形成されないと一般に 考えられていた．しかしながら，最近成熟脳でもシナ プス結合がダイナミックな変化を起こしていることを 示唆する実験的証拠が出てきた.

学習による新しいシナプス形成

塚原らはネコ中脳の赤核ニューロンのシナプス電位 を観察した結果，発芽によって新しいシナプスが形成 されたことを示唆するデータを得た．さらに大脳皮質 からの入力の刺激を条件刺激とする古典的条件付けの 際にも同様な結果が得られた $。$ この研究は学習に よって成熟脳においても新しいシナプスが形成された ことを示す先駆的なものである.

\section{シナプスのダイナミックな動き}

最近, Purves らはマウス交感神経節ニューロン上 のシナプスを in situ で巣光色素によって染め出し, その位置を一定期間後に繰り返し観察し画像解析する ことに成功した.すると10日後，3週間後にはシナプ スの数と位置は大きく変化していた .これが事実と すると成熟した哺乳動物のシナプスでも新しいシナブ スの形成や脱落などダイナミックな動きがあるのだが,

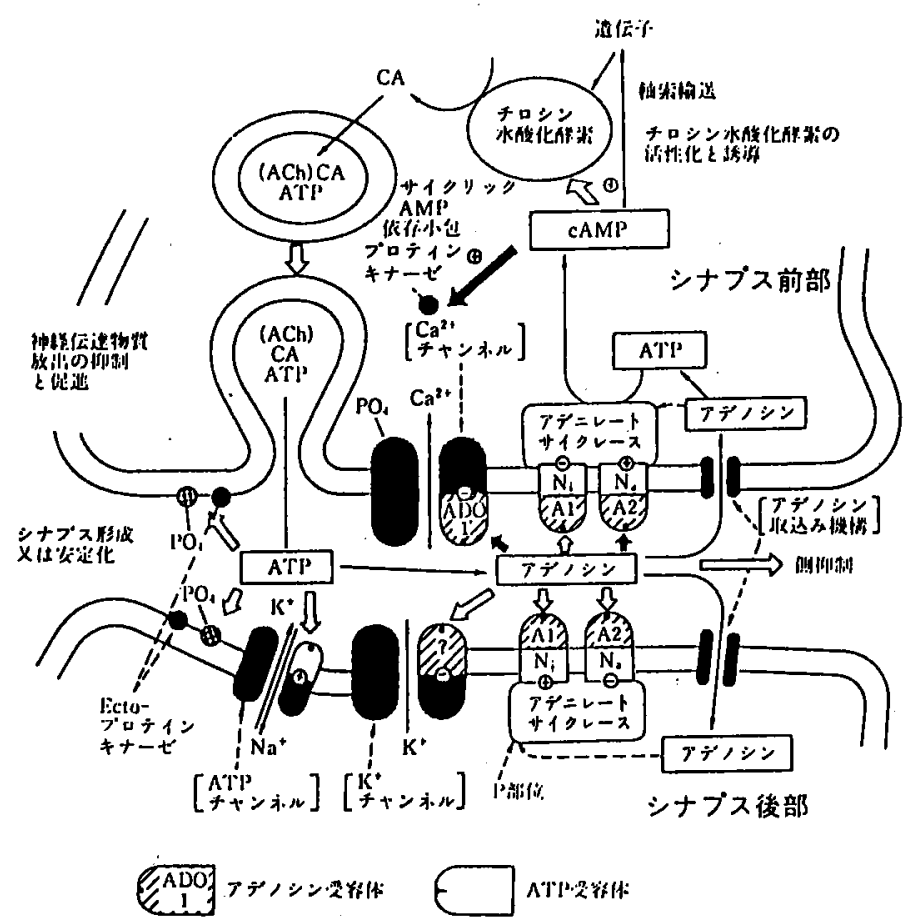

図 3. 高頻度刺激によりシナプス間で増加するATP とアデノシン関連物質が引き金となるさまざまな生化学的 カスケード (文献24を改玹)

$\Rightarrow$ : 神経伝達物質の放出を調節する，神経前 $\mathrm{Ca}_{\mathrm{a}}$ チャネルとカップリングしたアデノシンの直接作用と， 他のタイプのアデノシン受容体による神経前サイクリックAMPを介した作用. 詳しくは本文参照. ACh :アセチルコリン, CA：カテコールアミン. 
いままで観察技術がなかったために見過ごされていた ことになる。

\section{5.“トレーシング回路”モデルによる}

\section{長期記憶の説明}

前節で見て来たように, シナプス結合の可塑性が特 に大脳皮質連合野で成熟期迄続くとすると，長期記憶 のパターンが保持される為には, シナプスの選択的脱 落や発芽を通して安定化されなくてはならない.これ は“トレーシング回路”モデルでは次のように説明さ れる. まず“トレーシング回路”中のシナプスでは高 頻度刺激により PTP, LTP が起こる. 前者は数分, 後者は数時間以上継続するがいずれこのような一つの シナプスの伝達効率の変化 (促進) は減弱する. それ を引き継ぐシナブス競合と刺激頻度依存性の発芽（新 しいシナプス形成）はLTPの間に染備される，先ず 高頻度刺激により神経終末から側抑制物質が放出され る.この側抑制物質が細胞間隙を通り他の神経終末受 容体に達して, 低頻度刺激されているシナプス入力が 抑制され，場合によっては長期に継続して LTDにな る. そして，抑制されている終末を持つニューロンは 標的ニューロンから活動依存的に放出されている ニューロン生存因子を受け取れなくなる. 従って,

“トレーシング回路”中の活動性の高いシナプスの近 辺の, 或いは回路外の活動性の低いシナプスは脱落す ることになる. シナプスの脱落後には活動性の高い入 力の軸索から新しいシナプスが発芽して，空いている 膜表面を埋めて伝達効率を更に増大させる（図 2 ). このようなシナプス結合の形態的変化は LTPが減弱 し消滅しピても数年以上持続可能である. “トレーシ ング回路”モデルに従えば，長期記憶は回路のシナプ ス結合のパターンとして安定に維持されていくことに なる。

\section{6. シナプス伝達の調節における ATP と アデノシン関連物質の役割}

ここでは記憶過程でLTP, LTD の発生を制御する 可能性があり，且つシナブス競合における側抑制と促 進に役立つアデノシンと，発芽（シナプス形成）を促 進するATP の役割について述べる.

ATPはコリン作動性ニューロン或いはカテコール アミン作動性ニューロン神経終末のシナプス小胞中に 存在し，その主要な神経伝達物質と共にインパルス頻 度に比例して放出される 及びアデノシン関連物質はさまざまなイオンチャネル
に作用し，またプリン作動性ニューロンでは神経伝達 物質として働くことも判明して来た ${ }^{18)}$ 。また, これら によって脳切片中の cyclic AMP が增加する事も明ら かになっだ. また，筆者らのグループは，アデノシ ンがモルモット嗅脳皮質切片における興奮性シナプス 後電位を抑制する事を発見した ${ }^{201.211}$. 後にこの抑制作 用は高親和性アデノシン受容体 (ADO-1) ( $\mathrm{Al}$ と類 似）による $\mathrm{Ca}^{2+}$ チャルルの抑制により神経伝達物質 の放出量が隇少する事が明らかになっだ!。

それでは，ATP及びアデノシン関連物質の放出と それに由来する cyclic AMPの増加の持つ生理的意義 は一体何なのだろうか?

嗅脳皮質切片の実験系において，筆者等はATPゃ アデノシン関連物質を外液から取り除くが, 或いは ジブチリル cyclic AMPを加える事に依って, 電気刺 激による興奮性シナプス後電位が増大する事を見いだ した. アデノシン添加中に上昇したサイクリック AMPによる増強作用は，アデノシン添加中はより親 和性の強いアデノシン受容体を介した直接の抑制作用 に依ってマスクされているので，持続時間の長い増強 作用が顕在化する. またシナプトソーム中の cyclic AMP はアデノシン低親和性結合部位（ADO-2）を介 したアデノシン関連物質により増大しだ2.

こうした結果から，電気刺激の結果シナプス間隙に 放出されたアデノシン関連物質により神経終末中で cyclic AMPが増加し，これが, 例えばシナプス前 $\mathrm{Ca}^{2+}$ チャネルなどの機能蛋白質の cyclic AMP 依存性 リン酸化を介してシナプス伝達効率を上昇させる可能 性が考えられた（図 3 )。また，アデノシン関連物質 をモルモット線状体シナプトソームに与えると, cyclia AMP 濃度の上昇と共に, カテコールアミン合成の 律速段階に関与するチロシン水与酸化醭素の活性が上年 する事も明らかとなった ${ }^{25)}$. 即ち, 神経伝達物質生合 成の活性化及び誘導を通して, cyclic AMPがシナプ ス可塑性に関与する事も可能である.

では一体なぜ，ATP 及びアデノシン関連物質には， 直接作用としての神経伝達物質の放出抑制作用と, 細 胞内 cyclic AMP を介しての促進作用という 2 つの逆 の作用があるのであろうか?これら一見相反する $2 つ$ の作用は，前速したようにLTPとLTD の発生及び低 使用頻度シナプスの選択的除去過程と高使用頻度シナ プスの促通過程において重要な役割を果たしている可 能性が高い. 即ち，図4に示したように，ある入力が 刺激を受けると, 刺激頻度に比例したATP の放出が 起こり，シナプス間隙ではその分解物であるアデノシ 


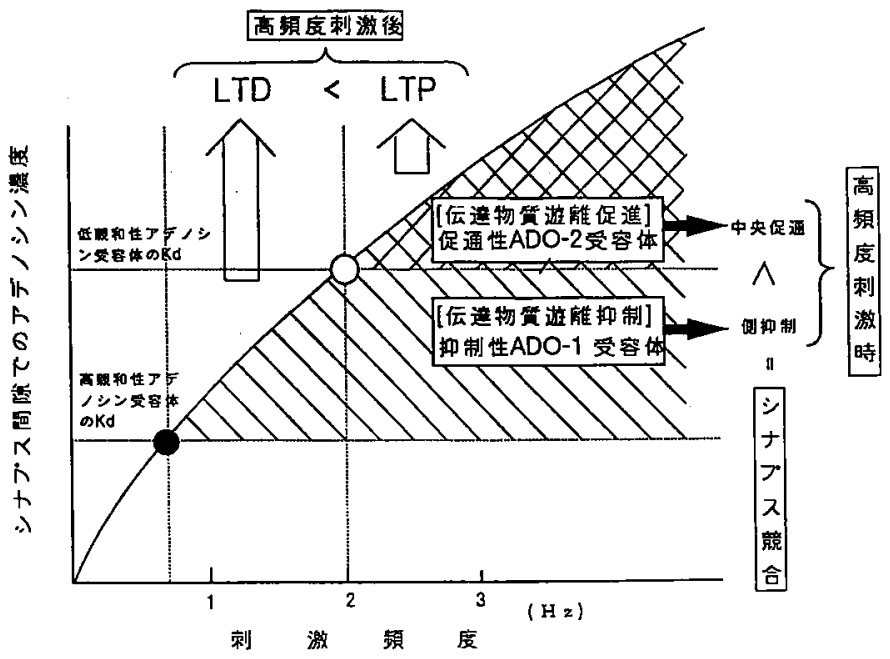

图 4. 刺激頻度によるシナブス間隙でのアデノシン関連物質の局所濃度と側抑制，中央促通の関係（文献32も参 照）およびLTP と LTD の発生機構の刺激頻度依存仮説.

刺激継続中および直後（約数分）までの短期効果では（中央）促通より（側）抑制が強く，見かけ上は 抑制だけが見える 行するが，LTPが起れば一般にLTP のみ観察されると考えられる.

ン関連物質の濃度が除去・不活性化作用に抗して刺激 依存性に高まる。これらが一定濃度（おそらく cyclic AMP を上昇させる低親和性受容体の kd 越えると cyclic AMPを介したさまざまな生化学変化がシナフ ス前・シナプス後でカスケード式に進行する。この結 果 LTPが起こる. 比較的低頻度刺激によるアデノシ ン㳻度の上昇は高親和性アデノシン受容体のみを活性 化し，直接の抑制またはLTDを起こす．LTDはLTP と拮抗し得るが高頻度刺激では LTP のみが見えてい てマスクされている。一方高頻度刺激されたシナブス 周辺から隣接シナブスに溢れ出たアデノシン関連物質 は高親和性アデノシン受容体を介して側抑制を行う。 その結果高頻度入カシナプスの周䢌のシナブスでは伝 達物質の放出が減少し，上り使用頻度の低いシナプス は除去される事になる。一方，使用頻度の高いシナブ スでは細胞内の低親和性アデノシン受容体を介して cyclic AMP が増加し，促通が起こり， feedbackして 来た強い抑制作用に拮抗し，シナプス伝達を保持でき るようにしている。このようにシナプス伝達効率は， 放出されるATP 及びアデノシン関連物質の濃度とシ ナプスの間隔により時間的にも空間的にもダイナミッ クに調節されうる。

\section{7. シナプスの形成・維持における ATP の役割}

シナプス間隙の ATP は ecto-ATP アーゼなどの基
質結合部位が細胞外膜上に存在する，いわゆる細胞外 醳素によってアデノシン関連物質に代謝される．近年， 細胞外に放出される ATP を必要とする新たな細胞外 醳素, ecto-プロテインキナーゼがニューロブラスト 一マ細胞で発見された $。$ また，ある種の ecto-プロ テインキナーゼがガングリオシド要求性を持つ事も明 らかになっだ．工藤らの開発した蛍光色素とビデオ 装置を用いた細胞内 $\mathrm{Ca}^{2+}$ イオン濃度観察システムを 用いて小倉らは培盖海馬ニューロン間でシナプス結合 を介する電気活動による同期した細胞内 $\mathrm{Ca}^{2+}$ の変動 を観察しだ。これらのシステムを利用して，筆者ら はラット培養大脳皮質ニューロン間のシナプス形成を in vitroで定量的に観察する事に成功した．この系に おいて，全く細胞内に侵入しないプロテインキナーゼ 阻害剤（K-252b）をこの采に作用させた結果，シナ プス形成は抑制された キナーゼの生理的意義は未だ推測の域を出ていないが， おそらく，インパルス頻度に比例して神経終末から放 出された ATPは，ある特定の細胞表層蛋白質を特異 的にリン酸化する ecto-プロテインキナーゼの基質と なり，その結果新しいシナプスの形成もしくは既存の シナブスの維持を行うのであろう．活動依存性に放出 されたATPがシナプス形成を促進し，記憶シナプス ひいては記憶ニューロン回路網のパターンを長期に安 定化させる事になる。 


\section{おわりに}

ヒト脳の長期記憶メカニズムについては，ヒト大脳 皮質連合野を中心として，余分なニューロンや尣長度 の高いシナプス結合の機能的な淘汰によるシナプス結 合の選択的保持が考えられる. 即ち繰り返し刺激を受 ける“トレーシング回路”中のシナプスのみがより優 位な入力をうけ，他のシナプスはシナプス競合に負け て脱落するとすれば，発生脳でのシナプス競合と同じ メカニズムで回路を構成するシナブス結合のみが強化 され，その回路は電気活動が終わった後でも長期的に 保持されるであろう。これにはシナプス結合の多重性 の持つダイナミックな機能的意味と樹状突起の発達が 大きく関与すると思われる。

以上の仮説が正しいとすれば，結局ヒトの成体脳に おける記憶は大脳皮質連合野の発達による機能未確定 なニューロン数の増加とそれらの間のランダムなシナ プス結合が外界からの刺激によって合目的に淘汰され る過程と考えることができる。.すなわち，大脳皮質連 合野では発生過程における脳の可塑性（ことにシナプ ス結合のダイナミックな可塑性) が発生終了後も部分 的に持続したものと考えられる。この様なヒト大脳皮 質連合野の発達遅延に関しては A. Portman が “ヒト はサルの生理的早産である”と述べた事実を考え合わ せる事も重要であろう。このような現象は古くから幼 形進化 ${ }^{301}$ として知られている. 即ち, ヒトはサルの胎 児期の段階で出生するという考えである。将来, 細 胞・分子レベルでヒトとサルの脳を詳しく比較できれ ば, 言語・思考能力など両者の脳の高次機能が大きく 異なる理由がよりいっそう明らかになるであろう。

\section{女 献}

1) Lorenz, K. "Studies in Animal and Human Behavior", Harvard Univ. Press, Cambridge, Mass. (1970).

2) Hubel, D. H., Wiesel, T. N.(1970) J. Physiol. (Lond)., 206. 419.

3) Hebb, D. O. "The Organization of Behavior" , Wiley, New York (1949).

4) Kuroda, Y.(1989)Neurochem. Intern., 14, 309.
5) Milner, B., Corkin, S., Teuber, H. L. (1968) Neuropsy chologia, 6, 215.

6) Ramón y Cajal, S. "Histologie du Systeme Nerveux de L'homme et des Vertebres ",vol. 1, Maloine, Paris(1911).

7) Lloyd, D. P. C. (1949) J. gen. Physiol. 33, 147.

8) Bliss, T. V. P. Lфmo, T. (1973)J. Physiol., 232, 331.

9) Ito M., Kano, M.(1982)Neurosci. Lett.,33, 253

10) Iijima T. et al.(1989)Soc. Neurosci. Abst.,15.

11) Dunwiddie \& Lynch, G. (1978) J. Physiol. (London), 276, 353.

12) Rogers, L. A., Cowan, W. M. (1973) J. comp. Neurol., 147. 291.

13) Rakic, P., Riley, K. P.(1983)Science, 219, 1441.

14) Wiesel, T. N., Hubel, D.H. (1965)J. Neurophysiol. 28, 1029.

15) Tsukahara, N., Oda, Y.(1981) Proc. Jpa. Acad. Ser. B, 57. 398.

16) Purves, D., Voyvodic, J. T., Magrassi, L., Yano, H.(1987) Science, 238, 1122.

17) Pull, I., Mcllwain, H. (1972)Biochem. J., 130, 975.

18) Burnstock, G.(1972)Phamacol. Rev., 24, 509.

19) Sattin, A.. Rall, T, W. (1970)Molec. Pharmacol., 6, 13; Research, 69, 211.

20) Kuroda, Y., Saito, M., Kobayashi, K. (1976) Brain Res., 109, 196.

21) Kuroda, Y. in "Adenosine Receptors and Moduration of Cell Functions"(V. Stefanovich eds.) pp235-240(1985).

22) Kuroda, Y.(1978)J. Physiol., Paris, 74, 463.

23) Kuroda, Y. "Physiology and Pharmacology of Adenosine Derivatives" (Daly, J. Kuroda, Y. Phillis, J. Shimizu, H. Li, M. eds.), Raven Press, New York (1983).

24）黑田洋一郎, 神経研究の進歩, (1986) 30, 634.

25) Kuroda, Y., Kobayashi, K. (1978) Proc. Jpn, Acad. Ser. B, 54, 640 .

26) Ehrlich, Y. H., Davis, T. B., Bock, E., Kornecki, E., Lenox, R. H.(1986)Nature, 320, 67.

27) Tsuji, S., Yamashita, T., Nagai, Y. (1988) J. Biochem., 104. 498.

28) Ogura, A., Ijjima, T., Amano, T., Kudo, Y.(1987)Neurosci. Lett., 78, 69.

29) Muramoto, K., Kobayashi, K., Nakanishi, S., Matsuda, Y., Kuroda, Y.(1988)Proc. Jpm. Acad. Ser. B, 64, 319.

30) Garstang, W.(1928)Q. J. Microscopiral Sci., 72, 51.

31）黒田洋一郎, (1990)蛋白翼核酸酵素, 35, 757.

\section{くろだ よういちろう}

昭和 41 年東京大学農学部農芸化学科卒, 46 年まで応用微生物研究所にて分子遺伝学を専 攻, 同年ロンドン大学精神医学研究所に留学, 神経生化学に転向, 48年から現職. 昔, 七 ミ, 蝶に熱中した昆虫少年. 今の趣味は, 野鳥, 野草など自然観察（最近はナチュラリス トという便利な言葉ができた). 他にテニス, ダイビング, 登山, 特に登山は学生時代に お世話になった故深田久弥さんの, 日本百名山の $\frac{2}{3}$ 以上を登った.

連絡先 $=183$ 府中市武蔵台2-6 東京都神経科学総合研究所 $\mathbf{0} 0423-25-3881$ 内線4003 